\title{
ENVIRONMENTALLY FRIENDLY FUEL USAGE: ECONOMIC MARGIN OF FEASIBILITY
}

\author{
PRZYJAZNE ŚRODOWISKU WYKORZYSTANIE PALIW: \\ ANALIZA EKONOMICZNA WYKONALNOŚCI
}

\begin{abstract}
In the world there are two main problems concerning energy and ecology. Despite the crude oil price fluctuation, it has tended to increase. Moreover fossil fuel burning emits hazard compounds, including greenhouse gas. To solve them alternative fuels for vehicle have to be used. In due to properties, their usage impacts on the engine efficiency. The alternative fuel usage needs additional investment costs on the vehicle engines adaptation and fuel supply infrastructure. So, decisions must be based on mathematical apparatus. Three submodels were used in the suggested mathematical model: energy and economic indicator for fuels; energy and economic indicator for vehicles; criteria for investment projects. As a criterion of investment projects the profitability index has been grounded. The mathematical model and the algorithm for determining the feasibility of the alternative fuel utilization have been developed. The proposed algorithm includes the following stages: calculation of the fuel energy cost; calculation of the criteria for vehicles; determining the maximum value of investments; making decisions. Biofuels and gaseous fuels for some countries have been studied. The economic attractiveness of the alternative transport fuels has been presented. According to mathematical modeling, gaseous fuels are more economically attractive compared with liquid biofuels. Among gaseous fuels, LPG has a higher economic efficiency. The economic margin of alternative fuel application feasibility has been determined.
\end{abstract}

Keywords: alternative fuel, profitability index, mathematical model for feasibility of the alternative fuel utilization, fuel energy cost, vehicle

\section{Introduction}

The last years a lot of attention was paid to improving the economic and environmental performance of vehicles due to global problems. Firstly, crude oil reserves are limited, and its price has a tendency to increase (Fig. 1) [1]. Secondly, the issue of pollutant and greenhouse gas emissions. Greenhouse gas emissions are under the control of the European Parliament [2]. One of the ways to solve the above problems is to use alternative motor fuels, including renewable ones. Alternative fuels (compared to using petrol and diesel fuel in vehicles) deliver greenhouse gas saving [\%]: biomethane - between 60 and 90 [3];

\footnotetext{
${ }^{1}$ University of Opole, ul. R. Dmowskiego 7-9, 45-365 Opole, Poland, phone +48 787321587

${ }^{2}$ Poltava State Agrarian Academy, ul. Skovorody 1/3, 36003 Poltava, Ukraine

${ }^{3}$ Mykolayiv National Agrarian University (Ukraine), 9 Georgiy Gongadze Str., Mykolayiv, Ukraine, 54020, phone +380501842688, email: havryshvi@mnau.edu.ua

*Corresponding author: akalinichenko@uni.opole.pl
} 
ethanol - between 30 and 82; biodiesel - between 38 and 50 [4]; liquefied petroleum gas up to 39 ; natural gas - between 25 and 47.

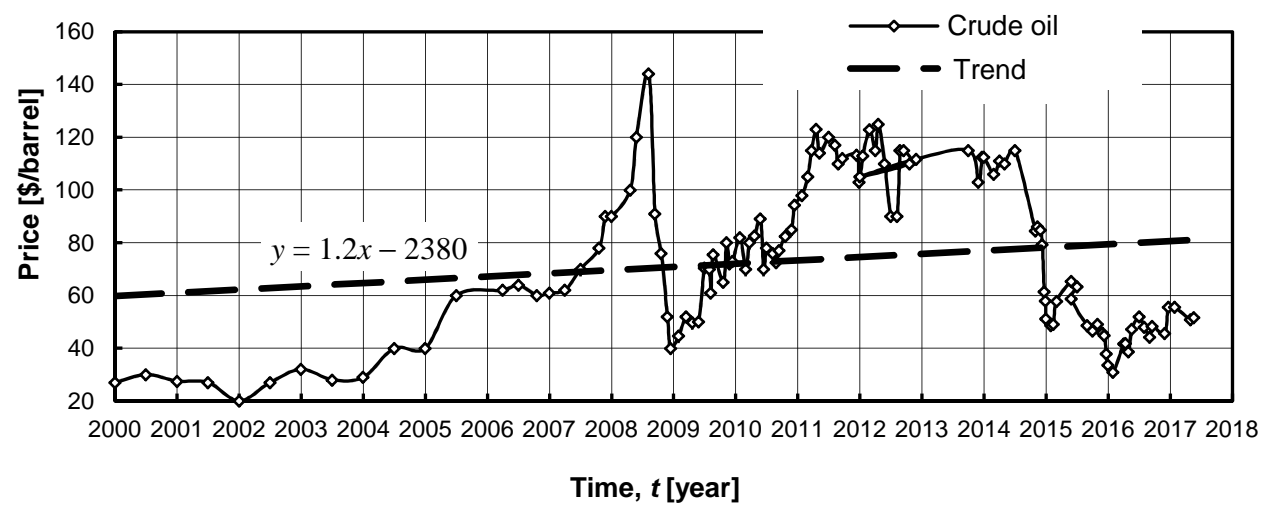

Fig. 1. Brent crude oil price history and its trend (modified by authors after WTRG [1])

The economic feasibility of alternative fuel use has been studied by a number of scientists. The researchers investigated the criteria to compare the different energy resources [5, 6]; the strategy of gaseous fuel application in a road transport [7-10]; an ecological and economic analysis of gaseous fuel usage [11-14]; economic evaluation of the alternative motor fuel utilization by road transportation were conducted $[15,16]$; a comparative analysis of motor fuels $[5,17]$. Problems and perspectives of the compressed natural gas (CNG) studied by many scientists [18-20].

However, there is still not enough studied into the usage of such indicators as the profitability index to ground of investment projects on the alternative fuel usage. The decision on the replacement of traditional fuels with alternative motor ones must be mathematically justified. It needs to determine economic indicators of investment projects.

\section{The purpose of this article}

The aim of this study is to develop a methodical approach to determine the feasibility of alternative fuels utilization. It was based in a criterion of an investment project and take into account both fuel energy indexes and investment costs.

\section{Material and methods}

This article presents retail prices of major alternative fuels, which are currently in widespread use, i.e. liquefied petroleum gas (LPG), CNG, biodiesel, bioethanol, etc.

Some submodels were combined to reach the aim: fuel energy costs, fuel efficiency indexes for vehicles, and a criterion of an investment project.

\section{Energy and economic indicator for fuels}

To make a decision on the application of a certain fuel it is necessary to have information both on their physical and chemical properties, and economic characteristics. 
One of them is fuel energy cost. In the case of mixed fuels cost of energy $(C E)$ is determined as follows:

$$
C E=\sum_{i=1}^{n}\left(F p r_{i} \cdot g_{i}\right) \cdot\left(\sum_{i=1}^{n}\left(Q_{i} \cdot \rho_{i} \cdot g_{i}\right)\right)^{-1}[€ / \mathrm{GJ}]
$$

where $F p r_{i}$ is the price of the $i^{\text {th }}$ component of the fuel $\left[€ / \mathrm{m}^{3}\right] ; Q_{i}$ is lower heat value of $i^{\text {th }}$ component of the fuel $[\mathrm{MJ} / \mathrm{kg}] ; \rho_{i}$ is the density of the $i^{\text {th }}$ component of the fuel $\left[\mathrm{Mg} / \mathrm{m}^{3}\right]$; $n$ is number of components; $g_{i}$ is share of the $i^{\text {th }}$ component of the fuel.

For dual fuel mode engines:

$$
C E=(1-\varphi) \cdot C E_{A}+\varphi \cdot C E_{C}[€ / \mathrm{GJ}]
$$

where $\varphi$ is the energy share of conventional fuel; $C E_{A}$ is the energy cost of conventional fuel [€/GJ]; $C E_{C}$ is the energy cost of alternative fuel [€/GJ].

Internal combustion engine efficiency depends on some factors, including the type of fuel. It is found that utilization of gaseous fuel in spark ignition petrol engine (especially biogas) results in efficiency reduction (relatively by up to $20 \%$ ) [21]. But the use of dual fuel mode in a spark ignition engine (petrol and biogas, petrol and natural gas) has quite different result. The brake thermal efficiency improves by $17 \%$ [22].

The use of biogas in dual fuel mode diesel engine has the same result - reducing the brake thermal efficiency. The utilization of natural gas can increase performance on some modes [23-25]. Transition from conventional petroleum fuels to biofuels changes the efficiency of thermal engines too [26-28].

Therefore, it is advisable to determine the energy cost per unit of useful work $(E C U W)$ :

$$
E C U W=C E \cdot \eta^{-1}=\sum_{i=1}^{n}\left(F p r_{i} \cdot g_{i}\right) \cdot\left(\eta \cdot \sum_{i=1}^{n}\left(Q_{i} \cdot \rho_{i} \cdot g_{i}\right)\right)^{-1} \quad[€ / \mathrm{GJ}]
$$

where $\eta$ is the engine performance at a certain fuel or fuel blend.

This mathematical model can be used to compare different types of fuel. The preferred fuel is the fuel with lower energy costs. The above indicators are more suitable for a stationary power plant. But the above factors do not take into account the fuel impact on vehicle efficiency as a transport system.

\section{Energy and economic indicators for vehicles}

The utilization of alternative fuels impacts on operational expenses of vehicles. They influence mileage, payload, traction force, etc. To evaluate a cumulative effect, dimensionless indicators may be used.

Utilization of alternative fuels may decrease payload of vehicle due to increasing operational weight. It may be the result of mounted additional equipment, for example, gas cylinders, gas generator, fuel tanks, etc.

So, the indicator for vehicles takes into account payload and cost of fuel:

$$
K_{A}=\sum_{i=1}^{n}\left(q a_{100 i} \cdot F p r_{i}\right) \cdot P L_{T} \cdot\left(F p r_{c} \cdot q c_{100} \cdot P L_{A}\right)^{-1}
$$

where $P L_{T}$ is vehicle payload when conventional fuel is used [Mg]; $P L_{A}$ is vehicle payload when alternative fuel is used $[\mathrm{Mg}] ; q c_{100}$ is conventional fuel consumption per mileage 
$\left[\mathrm{m}^{3} / 100 \mathrm{~km}\right] ; q a_{100 i}$ is $i^{\text {th }}$ alternative fuel consumption per mileage $\left[\mathrm{m}^{3} / 100 \mathrm{~km}\right] ; F p r_{c}$ is conventional fuel price $\left[€ / \mathrm{m}^{3}\right]$.

If the value of criterion $K_{A}$ is less than one $\left(K_{A}<1\right)$, the use of alternative fuel is expedient.

A traction force of the tractor when the engine is running on alternative motor fuels could be reduced as a result of the following reasons:

- $\quad$ an increase in operating weight;

- a decrease of engine power rating.

The first case is possible, for example, when using gas-bottled equipment. The second case is possible when alternative fuel property differs strongly from conventional ones. It is possible, for example, when using a gas generator. So, for tractors the value of a criterion is equal to the ratio of hourly cost of alternative and traditional fuels per $\mathrm{kN}$ thrust:

$$
K_{T}=\sum_{i=1}^{n}\left(\frac{b e_{i}}{\rho_{i}} \cdot F p r_{i}\right) \cdot N e_{a} \cdot \operatorname{Pcr}_{c} \cdot\left(\frac{b e_{c} \cdot N e_{c}}{\rho_{c}} \cdot F p r_{c} \cdot P c r_{a}\right)^{-1}
$$

where $N e_{c}$ is the nominal power rating when traditional petroleum-based fuel is used [kW]; $\mathrm{Pcr}_{c}$ is the traction force when traditional petroleum-based fuel is used [kN]; $b e_{c}$ is the specific fuel consumption of conventional fuel $[\mathrm{kg} / \mathrm{kWh}] ; \rho_{c}$ is the density of conventional petroleum fuels $\left[\mathrm{kg} / \mathrm{dm}^{3}\right] ; N e_{a}$ is the nominal power rating when alternative fuel is used $[\mathrm{kW}] ; \mathrm{Pcr}_{a}$ is the traction force when alternative fuels are used $[\mathrm{kN}] ; b e_{i}$ is the specific consumption of the $i^{t h}$ component of the alternative fuel $[\mathrm{kg} / \mathrm{kWh}] ; \rho_{i}$ is the density of the $i^{\text {th }}$ component of the alternative motor fuel $\left[\mathrm{kg} / \mathrm{dm}^{3}\right]$.

If the value of $K_{T}$ is less than 1 , then the use of alternative fuels is expedient. But criteria $K_{A}$ and $K_{T}$ do not take into account investment costs into infrastructure and modernization of vehicles.

\section{Selection criteria for investment projects}

For economic evaluation of investment projects four key indicators are used: the net present value $(N P V)$, the profitability index $(P I)$, the internal rate of return $(I R R)$ and payback period $(P P)$.

$N P V$ is an absolute indicator and it is used to analyze the profitability of investment projects. $N P V$ is calculated as the difference between the present values of cash inflows and outflows (during the project lifetime). A positive $N P V$ indicates that the projected earnings exceed the anticipated costs. Generally, if $N P V$ is positive, then an investment will be a profitable. This indicator has been used by the authors as a criterion in the optimization of biogas plants [29-31]. But this indicator is ambiguous.

The profitability index is an indicator that attempts to identify the relationship between benefits and the costs of a proposed project.

The $P I$ is calculated by dividing the present value of the project's future cash flows by the initial investment. If the $P I$ is less than 1.0 the project is unprofitable. This is a relative measure of the level of income per unit of input, i.e., the effectiveness of investments. That is why $P I$ can be used as a criterion of the investment project. In practice, an investment project may be accepted if $P I$ is more than 1.2.

Internal rate of return is an indicator which used to measure the profitability of potential investments. 
The period during which the consumer may recover the initial investment is called payback period. This is one of many simple and accessible indicators.

Not all indicators may be used as criterion of investment projects. Such as, payback period and net present value cannot give single-valued result. And calculation procedure for the internal rate of return is relative complicated. Based on the above, we accept the profitability index as a criterion of an investment project.

\section{Mathematical model and the algorithm for determining the feasibility of the alternative fuels utilization}

Profitability index of regular cash flow is determined as follows:

$$
P I=\frac{C_{c}-C_{A}}{V} \cdot \sum_{i=1}^{n}\left((1+0.01 \cdot g)^{-i}\right)
$$

where $C_{c}$ is the annual cost of conventional fuels consumption [€]; $C_{A}$ is the annual cost of alternative fuels consumption [€]; $g$ is the discount rate [\%]; $V$ - total initial investment cost $[€] ; n$ is the lifetime of the investment project [years].

To evaluate the investment projects it is necessary to know the discount rate value. The discount rate is the interest rate used to convert future revenue streams into a single value of the current value. It is used to assess the effectiveness of investments. In economic terms, the discount rate is the rate of return on invested capital, which is required by the investor. Therefore, the value of the discount rate impacts on key decisions.

Determination of the discount rate of investment projects for alternative energy source utilization was investigated earlier by the authors. It is based on fuel prices and takes into account the market dynamics [32].

After transformation the equation (6) will have a form:

$$
P I=C_{c} \cdot\left(1-\frac{C_{A}}{C_{c}}\right) \cdot \frac{\sum_{i=1}^{n}\left(\frac{1}{(1+0.01 \cdot g)^{i}}\right)}{V}
$$

We introduce the following notations $\beta=\frac{C_{A}}{C_{c}}$ and $\gamma=\frac{V}{C_{c}}$, then the equation (7) takes the form:

$$
P I=\frac{(1-\beta)}{\gamma} \cdot \sum_{i=1}^{n}\left((1+0.01 \cdot g)^{-i}\right)
$$

The $\beta$ depends on fuel price and engine brake thermal efficiency:

$$
\beta=\frac{C_{A}}{C_{c}}=\frac{C E_{A}}{C E_{c}}=\frac{F p r_{A} \cdot \eta_{c}}{F p r_{c} \cdot \eta_{A}}
$$

where $\eta_{c}$ is the engine performance at conventional fuel; $\eta_{A}$ is the engine performance at alternative fuel.

To determine the expenditure for different fuels, it is necessary to take into account the additional costs associated with reducing their use. These may be, for example, environmental charges, taxes on the vehicles, etc. It covers all areas: from investment in 
fuel production to environmental charges [33-37]: reducing income taxes; government award for eco-friendly cars; reducing taxes on gas-cylinder cars, etc.

For example, in Sweden, the new environmentally-friendly cars are exempt from taxes for five years. For comparison, the annual environmental payments from diesel vehicles are $460 €$, and petrol $-230 €$.

That is why factor $\beta$ has a following form:

$$
\beta=\frac{C_{A}-C R}{C_{c}}
$$

where $C R$ is the cost reducing [€].

The investment project is attractive, if the Profitability Index is more than 1.2. Then the equation (3) takes the form:

$$
\frac{(1-\beta)}{\gamma} \cdot \sum_{i=1}^{n}\left((1+0.01 \cdot g)^{-i}\right)>1.2
$$

From the equation (10) the value of $\gamma$ can be found as:

$$
\gamma<\frac{(1-\beta)}{1.2} \cdot \sum_{i=1}^{n}\left((1+0.01 \cdot g)^{-i}\right)
$$

It is a condition for the attractiveness of alternative fuels application. The critical ratio of investment to the annual cost of conventional fuel consumed has a following form:

$$
\gamma_{0}=\frac{(1-\beta)}{1.2} \cdot \sum_{i=1}^{n}\left((1+0.01 \cdot g)^{-i}\right)
$$

The factor $\gamma_{0}$ determines the economic margin for alternative fuel application. The function $\gamma$ has linear dependence on $\beta$. In our example, the lifetime of the project is assumed equal to 8 years (Fig. 2). So if we have annual costs on conventional and alternative fuels, we can find maximum acceptable value of investment costs:

$$
V_{\max }=\gamma_{0} \cdot C_{c} \cdot[€]
$$

We propose the following algorithm to determine the feasibility of using alternative fuel utilization - Figure 3.

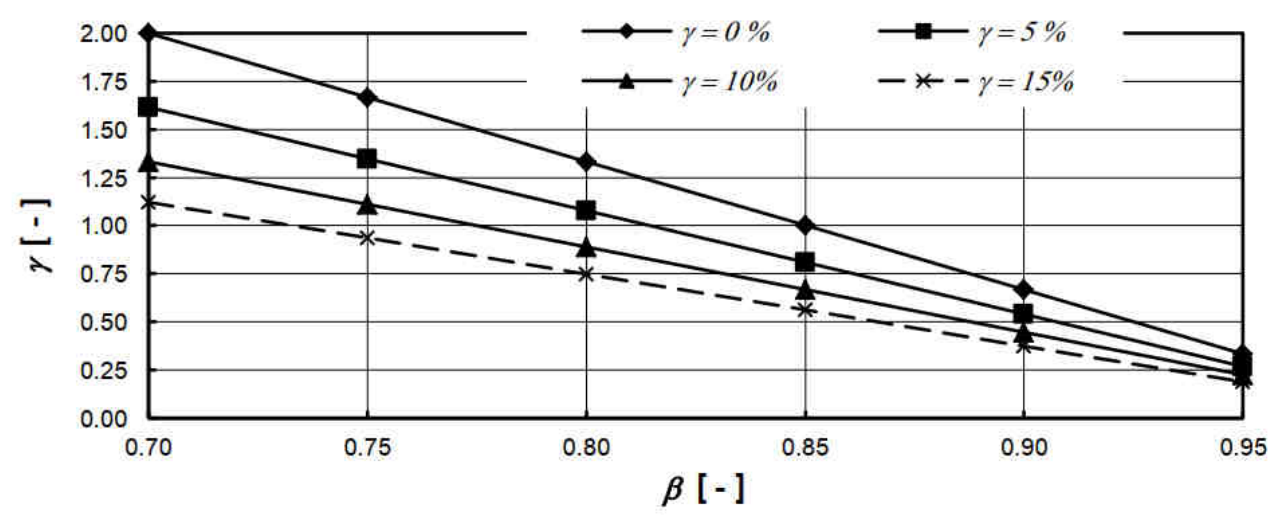

Fig. 2. Dependence of $\gamma$ on $\beta$ 
Initial data:

- traditional and alternative fuels prices;

- the main physical properties of fuels;

- characteristics of vehicle using different types of fuels;

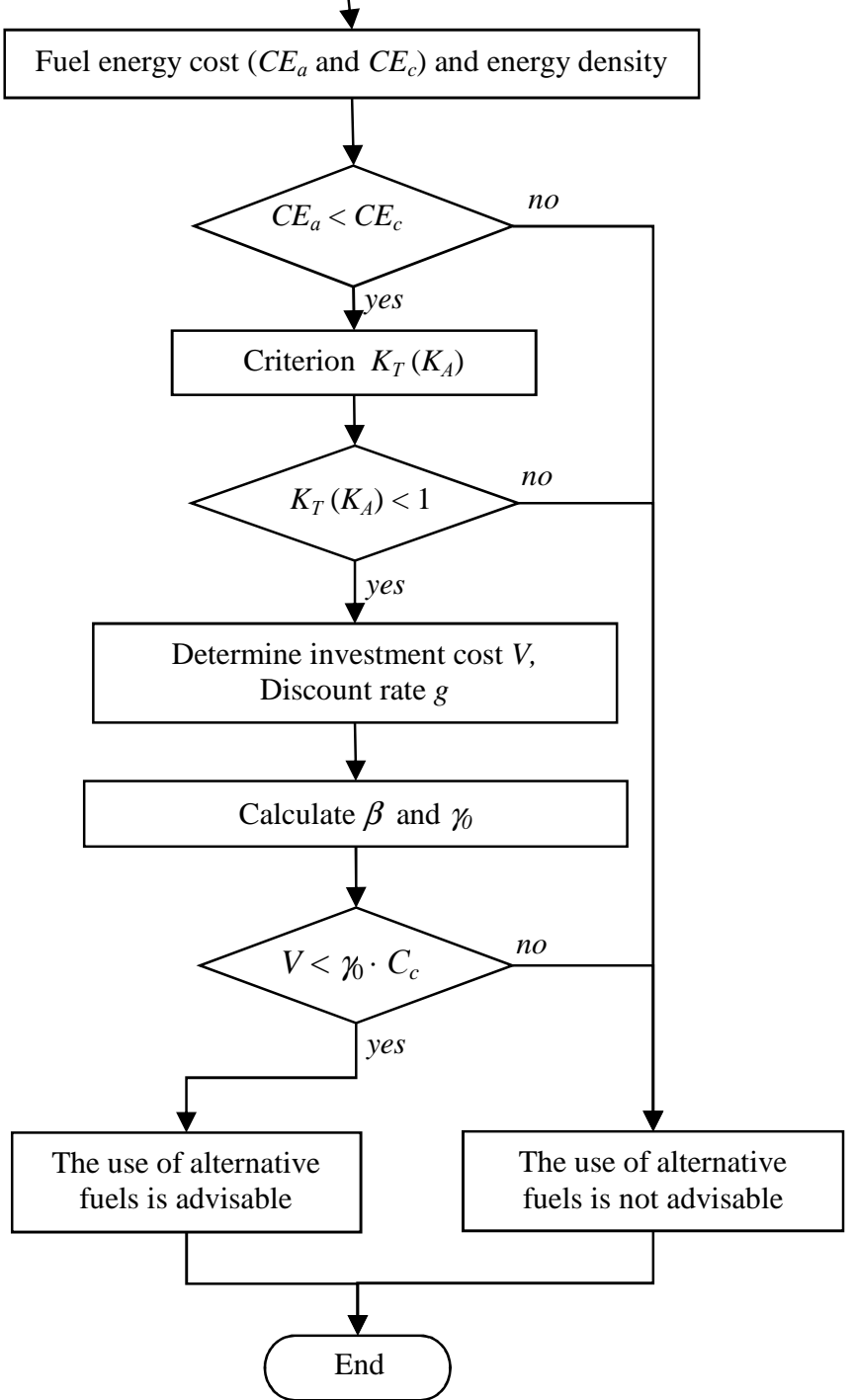

Fig. 3. The algorithm makes decisions on alternative fuel use 


\section{Results of modelling}

The situation of the fuel market in some countries has been considered. The reason for choosing them are as follows:

- The USA is the world leader in biofuel production and utilization,

- France and Germany are the EU leaders in alternative fuel utilization,

- Poland is the nearest neighbor of Ukraine and has the nearest area and history,

- Sweden is the leader of biomethane usage as road fuel,

- Russia is a huge exporter of energy resources and a neighbor of Ukraine.

Biofuel consumption is developing now. In EU countries biodiesel and bioethanol are more popular fuels in transport. Besides biogas and pure vegetable oil are being used.

Prices of motor fuels $\left[€ / \mathrm{dm}^{3}\right],\left[* € / \mathrm{m}^{3}\right]$

Table 1

\begin{tabular}{|c|c|c|c|c|c|c|c|}
\hline \multirow{2}{*}{ Fuel } & \multicolumn{7}{|c|}{ Countries } \\
\hline & Ukraine & Poland & Germany & France & Sweden & USA & Russia \\
\hline \multicolumn{8}{|c|}{ Non-renewable fuels } \\
\hline Diesel fuel & 0.78 & 1.05 & 1.24 & 1.21 & 1.40 & 0.56 & 0.66 \\
\hline Gasoline super & 0.85 & 1.09 & 1.44 & 1.36 & 1.45 & 0.59 & 0.63 \\
\hline LPG & 0.41 & 0.50 & 0.57 & 0.75 & 0.94 & 0.59 & 0.27 \\
\hline $\mathrm{CNG}^{*}$ & 0.52 & 0.79 & 0.78 & 0.95 & 1.31 & 0.51 & 0.24 \\
\hline \multicolumn{8}{|c|}{ Renewable fuels } \\
\hline Rapeseed oil $^{* *}$ & 0.69 & & & & & & \\
\hline Biodiesel B100 & & & & & & 0.77 & \\
\hline E10 & & & 1.42 & 1,35 & & 0.58 & \\
\hline E85 & & & & 0.64 & 1.14 & 0.48 & \\
\hline
\end{tabular}

*Calculated from $€ / \mathrm{kg} ;{ }^{* *}$ Calculated from $€ / \mathrm{Mg}$, no extra tax included

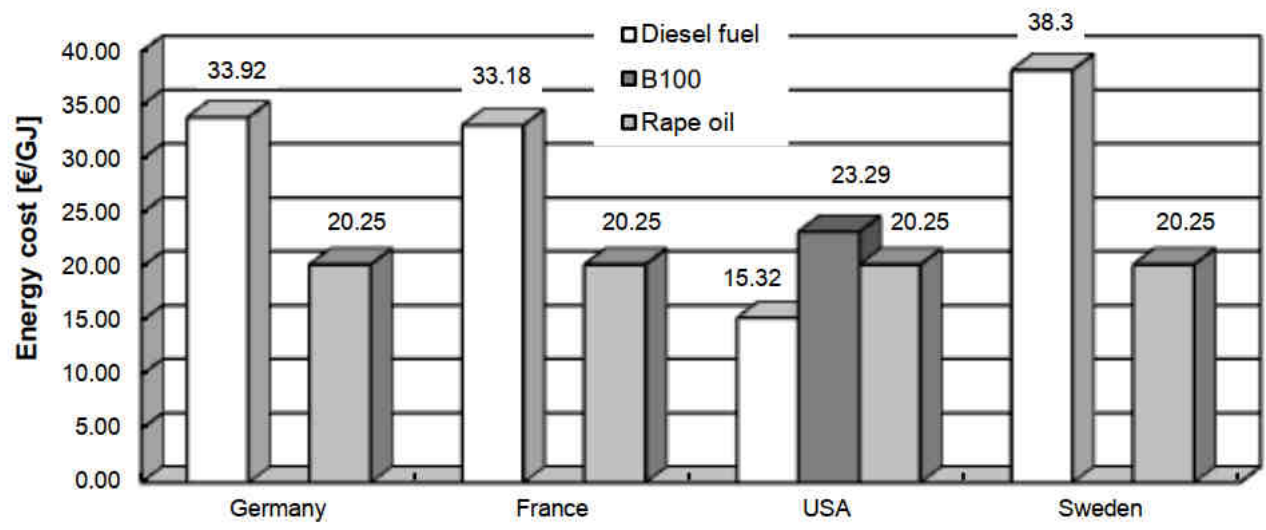

Fig. 4. The energy cost for diesel engines: petroleum and biofuels

Biomethane is a renewable gaseous fuel produced through upgrading biogas and can meet all technical requirements for vehicles. Now seven countries of EU have biomethane filling stations: Austria, Finland, Germany, Hungary, Netherland, Sweden, and Switzerland 
[38]. Germany, Sweden and Finland are leaders in biomethane utilization as transport fuel [39].

In this paper the fuel prices were considered, which have emerged on April 2017 (Table 1) [40-49]. According to our calculations, energy costs of biofuels are often higher compared with traditional fuels (Figs. 4 and 5).

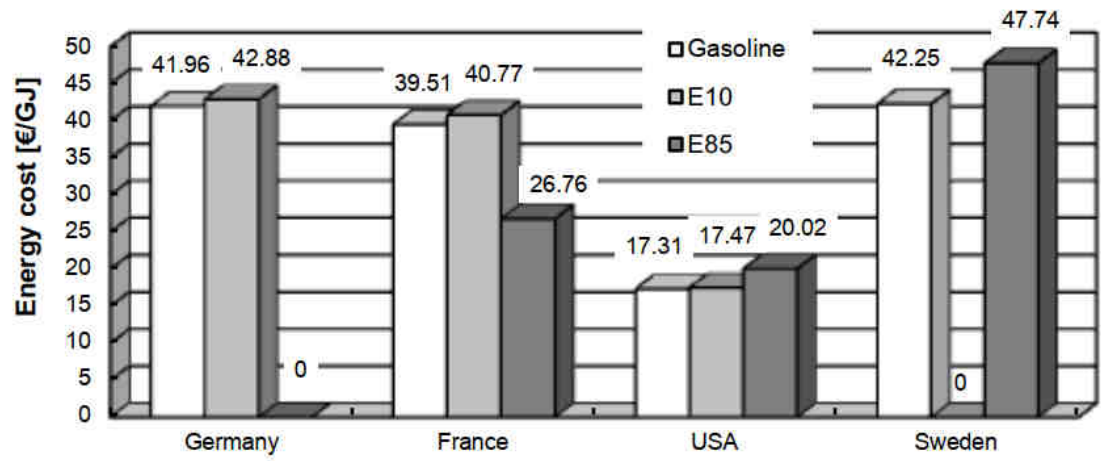

Fig. 5. The energy cost of fuels for spark ignition engines: petroleum and biofuels

Thus in Germany, the use of biodiesel and rapeseed oil are expedient communal transport. And these biofuels are not attractive for agriculture. This is due to the fact that farmers buy diesel fuel at a discount price (57\% of the average prices in the country) [50].

Gaseous fuels are more economically advisable compared with biofuels. The coefficient $\beta$ depends on the fuel being replaced and the market price. In different countries, it is in the range from 0.394 to 1.487 (Table 2).

Table 2

The values of the coefficient $\beta$

\begin{tabular}{|c|c|c|c|c|c|c|c|}
\hline \multirow{2}{*}{ Fuel } & \multicolumn{7}{c|}{ Countries } \\
\cline { 2 - 8 } & Ukraine & Poland & Germany & France & Sweden & USA & Russia \\
\hline \multicolumn{7}{|c|}{ Compression ignition engines } \\
\hline LPG & 0.744 & 0.676 & 0.652 & 0.871 & 0.953 & 1.487 & 0.580 \\
\hline CNG & 0.731 & 0.821 & 0.683 & 0.814 & 1.018 & 0.995 & 0.394 \\
\hline \multicolumn{7}{|c|}{ Spark ignition engines } \\
\hline LPG & 0.641 & 0.611 & 0.527 & 0.732 & 0.864 & 1.317 & 0.571 \\
\hline CNG & 0.695 & 0.818 & 0.608 & 0.753 & 1.017 & 0.971 & 0.427 \\
\hline
\end{tabular}

For spark ignition engines the values of the coefficient $\gamma$ (zero discount rate) is higher compared with diesel engines (Figs. 6 and 7). This fact makes the use of alternative gaseous fuels more attractive for road transport equipped with petrol engines. For some countries, for example, in the United States the replacement of petroleum fuels with LPG is not advisable. 


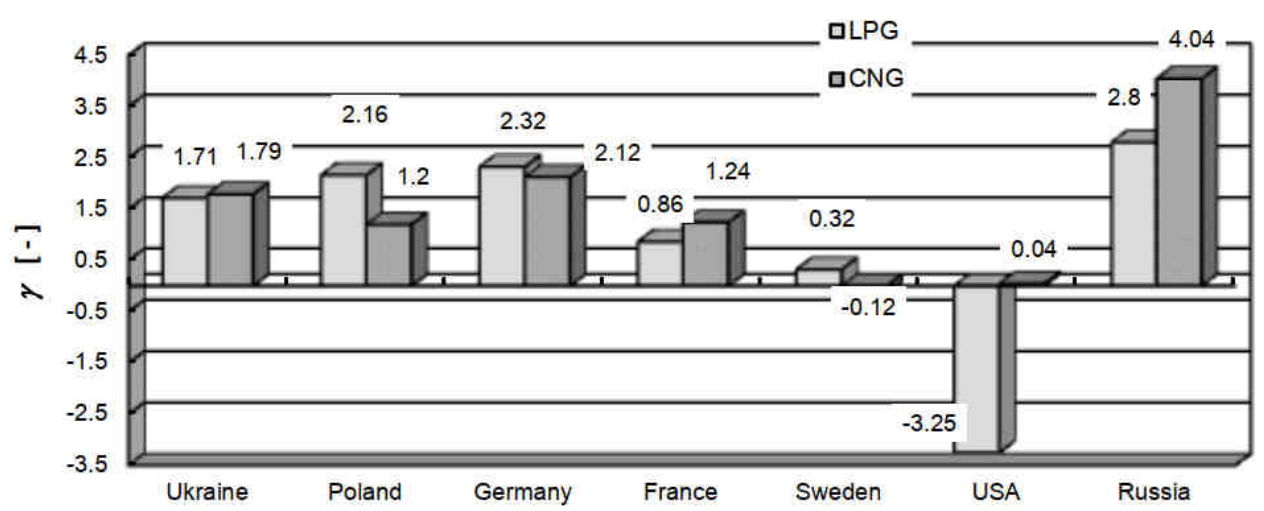

Fig. 6. Coefficient $\gamma$ in different countries (compression ignition engines)

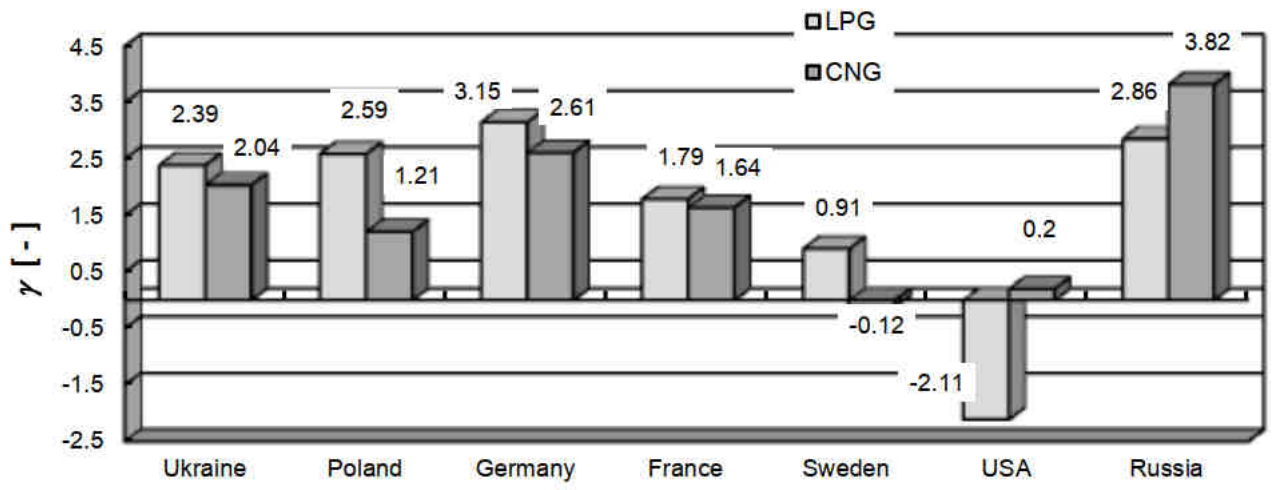

Fig. 7. Coefficient $\gamma$ in different countries (spark ignition engines)

There are several barriers hindering the development of this type of fuel. One of the key barriers is the lack of infrastructure of filling stations [9, 19]. The similar situation is in the United States. This is typical situation for countries with a large territory.

In general terms, this pattern is common, regardless of the country (Fig. 8).

The above model may be used to determine the minimum annual vehicle distance traveled to make alternative fuel use attractive:

$$
D_{C}={\frac{V_{i c}}{\gamma \cdot q c_{100} \cdot F p r c}}^{[\mathrm{km}]}
$$

where $V_{i c}$ is increment cost of alternative fuel vehicle [€].

Let us consider modeling of gaseous fuel usage in Ukraine. Petrol-powered and diesel-powered vehicles were studied. The switch to gaseous fuel, truck owners can purchase LPG or CNG vehicles produced by truck manufacturers or convert their petrol-powered or diesel-powered vehicles into gaseous fuels. In our case KamAZ 53208 is 
equipped with the dual fuel mode diesel engine by a manufacturer. GAZ 3307 is powered by a petrol engine. There are available LPG and CNG conversion kits for this truck.

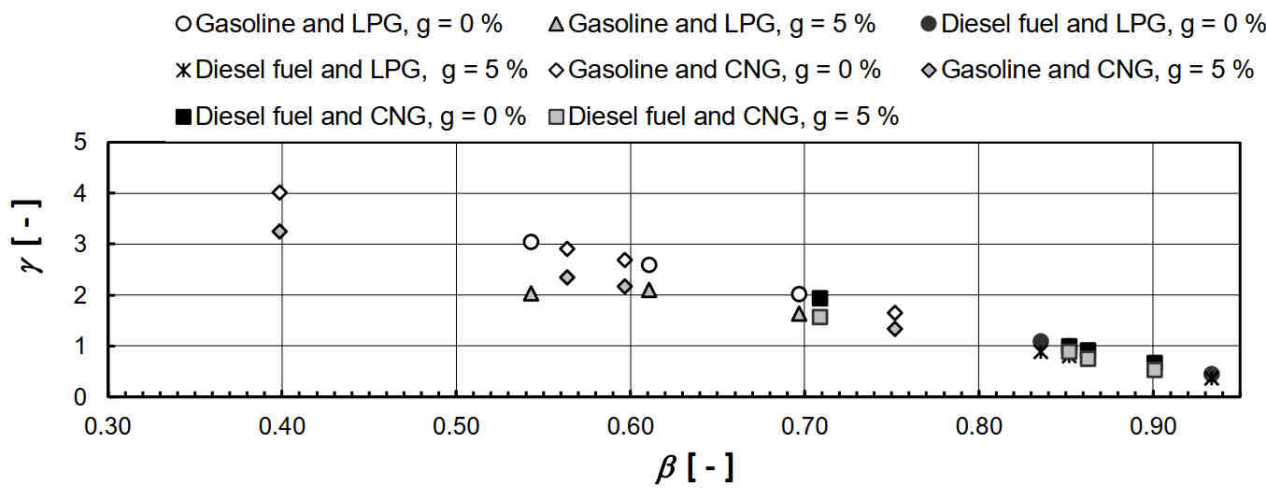

Fig. 8. Dependence $\gamma$ on the $\beta$

The results are follows. Investments in LPG powered vehicles are covered faster than in CNG vehicles (Tables 3 and 4).

GAZ 3307 (spark ignition engine)

\begin{tabular}{|l|c|c|c|}
\hline \multicolumn{1}{|c|}{ Item } & \multirow{2}{*}{ Unit } & \multicolumn{2}{c|}{ Gaseous fuel } \\
\cline { 3 - 4 } & & LPG & CNG \\
\hline Energy cost & {$[€ / G J]$} & 16.13 & 15.57 \\
\hline$K_{A}$ & {$[-]$} & 0.604 & 0.617 \\
\hline$\beta$ & {$[-]$} & 0.604 & 0.617 \\
\hline$\gamma_{0}$ & {$[-]$} & 3.3 & 3.19 \\
\hline Increment cost for gaseous fuel equipment & {$[€]$} & 430 & 1800 \\
\hline Minimum annual conventional fuel consumption & {$[€]$} & 130.3 & 563.9 \\
\hline Minimum annual vehicle distance traveled & {$[\mathrm{km}]$} & 646 & 2794 \\
\hline
\end{tabular}

KamAZ 53208 (compression ignition engine)

\begin{tabular}{|l|c|c|c|}
\hline \multicolumn{1}{|c|}{ Item } & \multirow{2}{*}{ Unit } & \multicolumn{2}{c|}{ Dual fuel mode } \\
\cline { 3 - 4 } & & Diesel fuel & CNG \\
\hline Energy cost & {$[€ / \mathrm{GJ}]$} & 21.28 & 15.57 \\
\hline & {$[€ / \mathrm{GJ}]$} & \multicolumn{2}{|c|}{16.94} \\
\hline Energy share & {$[\%]$} & 23.9 & 76.4 \\
\hline$K_{A}$ & {$[-]$} & \multicolumn{2}{|c|}{0.832} \\
\hline$\beta$ & {$[-]$} & \multicolumn{2}{|c|}{0.796} \\
\hline$\gamma_{0}$ & {$[-]$} & 1.7 \\
\hline Increment cost for gaseous fuel equipment & {$[€]$} & 2300 \\
\hline Minimum annual conventional fuel consumption & {$[€]$} & \multicolumn{2}{|c|}{1352.9} \\
\hline Minimum annual vehicle distance traveled & {$[\mathrm{km}]$} & 6688 \\
\hline
\end{tabular}




\section{Conclusions}

To reduce the hazardous emissions of vehicle engines, alternative fuels may be used.

As a rule, liquid biofuels are more expensive compared with petroleum fuels. Exception is E85 in France and pure vegetable oil. Gaseous fuels are more economically attractive. The exception is LPG in the USA and CNG in Sweden. Russia and Germany have a larger range for investment value in vehicle gaseous fuel infrastructure and modernization of transport facility.

The profitability index has been proved as a criterion of investment projects for alternative fuel utilization. To make decisions about appropriate alternative fuel, mathematical model and algorithm have been developed. Results of the above algorithm work have been presented. The analysis shows that the most expedient is the use of gaseous fuels with vehicles equipped with spark-ignition engines. Among gaseous fuels LPG has better economic efficiency.

\section{References}

[1] Williams JL. WTRG Economics. London; 2017. http://wtrg.com/.

[2] Report from the Commission to the European Parliament, the Council, the European Economic and Social Committee and the Committee of the Regions. Renewable Energy Progress Report. Brussels, 01.02.2017 $\operatorname{COM}(2017) \quad 57 \quad$ final. http://eur-lex.europa.eu/legal-content/EN/TXT/PDF/ ?uri=CELEX:52017DC0057\&from=EN

[3] Bates J. Biomethane for Transport from Landfill and Anaerobic Digestion. Final report. Report for the Department for Transport (PPRO 04/91/63). Ricardo-AEA. 06/03/2015. https://www.gov.uk/government/uploads/system/uploads/attachment_data/file/416002/biomethane-fortransport.pdf.

[4] Bereczky A. Alternative fuels and technologies for compression ignition internal combustion engines. J KONES. 2012:19(4):1-9. http://yadda.icm.edu.pl/yadda/element/bwmeta1.element.baztech-article-BUJ80020-0005/c/httpwww_bg_utp_edu_plartkones42012j20o20kones20201220no20420vol_201920 bereczky.pdf.

[5] Hall CAS, Lambert JG, Balogh SB. EROI of different fuels and the implications for society. Energy Policy. 2014;64:141-152. DOI: 10.1016/j.enpol.2013.05.049.

[6] Kalghatgi G. Is it really the end of internal combustion engines and petroleum in transport? Appl Energy. 2018;225:965-974. DOI: 10.1016/j.apenergy.2018.05.076.

[7] Use of gaseous fuels in transport. REA Renewable Transport Group. 2016. https://www.r-e-a.net/upload/ rea_use_of_gaseous_fuels_in_transport_report-_april_2016-_final.pdf.

[8] Jaffe AM, Dominguez-Faus R, Lee A, Medlock K, Parker N. Scheitrum D, et al. Exploring the role of natural gas in U.S. trucking. UC Davis Institute of Transportation Studies. 2015: 63. UCD-ITS-RR-15-05. https://www.ge.com/sites/default/files/2015\%2002\%20Exploring\%20the\%20Role\%20of\%20Natural\%20Ga s\%20in\%20US\%20Trucking.pdf.

[9] Study of Opportunities for Natural Gas in the Transportation Sector. Marbek. 2010; project ID: $29064: 78$. http://www.xebecinc.com/pdf/Marbek-NGV-Final-Report-April-2010.pdf.

[10] Mikolajková-Alifov M, Pettersson F, Björklund-Sänkiaho M, Saxén HA. Model of optimal gas supply to a set of distributed consumers. Energies. 2019;12(3):351. DOI: 10.3390/en12030351.

[11] Kalinichenko A, Havrysh V, Perebyynis V. Evaluation of biogas production and usage potential. Ecol Chem Eng S. 2016;23(3): 387-400. DOI: 10.1515/eces-2016-0027.

[12] Gahleitner G, Lindorfer J. Alternative fuels for mobility and transport: Harnessing excess electricity from renewable power sources with power-to-gas. ECEEE Summer Study Proc. 2013;4-133-13:1007-1018. http://proceedings.eceee.org/papers/proceedings2013/4-133-13_Gahleitner.pdf.

[13] Gabbar HA, Ayoub N. Integrated modeling for optimized regional transportation with compressed natural gas fuel. Alexandria Eng J. 2016;55(1):533:545. DOI: 10.1016/j.aej.2015.10.007.

[14] Topal O, Nakir I. Total cost of ownership based economic analysis of diesel, CNG and electric bus concepts for the public transport in Istanbul City. Energies. 2018;11(9):2369. DOI: 10.3390/en11092369.

[15] Hall CAS, Cleveland CJ. EROI: definition, history and future implications. ASPO-US Conf, Denver. 2005. www.esf.edu/efb/hall/talks/EROI6a.ppt. 
[16] Fernández-Dacosta C, Shen L, Schakel W, Ramirez A, Kramer GJ. Potential and challenges of low-carbon energy options: Comparative assessment of alternative fuels for the transport sector. Appl Energy. 2019;236:590-606. DOI: 10.1016/j.apenergy.2018.11.055.

[17] Mofijur M, Rasul MG, Hyde J, Bhuyia MMK. Role of biofuels on IC engines emission reduction. Energy Proc. 2015;75:886-892. DOI: 10.1016/j.egypro.2015.07.211.

[18] Chris LF. The prospects for natural gas as a transport fuel in Europe. OIES Paper. 2014;84:1-109. https://www.oxfordenergy.org/wpcms/wp-content/uploads/2014/03/NG-84.pdf.

[19] Chikishev E, Ivanov A, Anisimov I., Chainikov D. Prospects of and problems in using natural gas for motor transport in Russia. VII Int Sci Pract Conf "Innovative Technologies in Engineering". IOP Conf. Series: Mater Sci Eng. 2016;142(012110):1-8. DOI: 10.1088/1757-899X/142/1/012110.

[20] Llera E, Romeo LM, Bailera M, Osorio JL, Ebro CR, de Luna M. Exploring the integration of the power to gas technologies and the sustainable transport. Intern J Energ Prod Manage. 2018:3(1):8. DOI: 10.2495/EQ-V3-N1-1-9.

[21] Patel AB, Patel KA, Umrigar PB, Joshi A, Patel VC. Effect of ignition energy on performance and emission of dedicated 4-stroke single cylinder S.I engine fuelled with biogas - An experimental investigation. Int J Sci Technol Eng. 2015;1(11):391-399. http://www.ijste.org/articles/IJSTEV1I11096.pdf.

[22] Ayade M, Latey AA. Performance and emission characteristics of biogas - petrol dual fuel in SI engine. Int J Mechanic Eng Technol (IJMET). 2016;7(2):45-54. http://www.iaeme.com/MasterAdmin/ uploadfolder/IJMET_07_02_006/IJMET_07_02_006.pdf.

[23] Liu J, Yang F, Wang H, Ouyang M, Hao S. Effects of pilot fuel quantity on the emissions characteristics of a CNG/diesel dual fuel engine with optimized pilot injection timing. Appl Energy. 2013;110:201-206. DOI: 10.1016/j.apenergy.2013.03.024.

[24] Kapilan N, Ashok Babu TP, Reddy RP. Improvement of performance of dual fuel engine operated at part load. Int J Automot Mech Eng (IJAME). 2010;2:200-210. https://core.ac.uk/download/pdf/35361474.pdf.

[25] Senthilkumar K, Vivekanandan S. Investigating the biogas as secondary fuel for Ci engine. Int J Appl Environ Sci (IJAES). 2016;11(1):155-163. https://www.ripublication.com/ijaes16/ijaesv11n1_12.pdf.

[26] Subramanian KA, Singal SK, Saxena M, Singhal S. Utilization of liquid biofuels in automotive diesel engines: An Indian perspective. J Biomass Bioenergy. 2005:29:65-72. DOI: 10.1016/j.biombioe.2005.02.001.

[27] Yuen P, Villaire W, Beckett J. Automotive materials engineering challenges and solutions for the use of ethanol and methanol blended fuels. SAE Technical Paper. 2010-01-0729. DOI: 10.4271/2010-01- 0729.

[28] Rose K, Hamje H, Jansen L, Fittavolini C, Clark R, Dolores M et al. Impact of FAME content on the regeneration frequency of diesel particulate filters (DPFs). SAE Int. J. Fuels Lubr. 2014;7(2):563-570. DOI: 10.4271/2014-01-1605.

[29] Kuglarz M, Grübel K. Integrated production of biofuels and succinic acid from biomass after thermochemical pretreatments. Ecol Chem Eng S. 2018;25(4):521-536. DOI: 10.1515/eces-2018-0034.

[30] Kalinichenko A, Pasichnyk L, Osypenko S, Patyka V, Usmanova H, Bacterial diseases of bioenergy plants. Ecol Chem Eng A. 2017:24(2):169-191. DOI: 10.2428/ecea.2017.24(2)16.

[31] Huliaieva H, Tokovenko I, Maksin V, Kaplunenko V, Kalinichenko A. Effect of nanoaquacitrates on physiological parameters of Fodder Galega infected with phytoplasma. Ecol Chem Eng S. 2018:25(1):153-158. DOI: 10.1515/eces-2018-0011.

[32] Havrysh V. Features of determination of discount rate for energy producing investment projects. Ukrainian Black Sea Region Agrarian Sci. 2014;3(79-1):23-35. http://visnyk.mnau.edu.ua/en/n79v3r2014t1havrysh/.

[33] Ekman M. Biomethane in Sweden: Governmental Incentives and Market Trends. Glob Biomethane Congr. 2012. http://european-biogas.eu/wp-content/uploads/files/2013/11/5-Michelle_Ekman_ Governmental-Incentives-and-Market-Trends_Developments-in-the-Swedish.pdf.

[34] Rydberg T, Belhaj M, Bolin L, Lindblad M, Sjödin Å, Wolf C. Market conditions for biogas vehicles. Swedish Environmental Research Institute Ltd.; 2010. http://www.ivl.se/download/ 18.343dc99d14e8bb0f58b75d6/1446478742726/B1947.pdf.

[35] IEA Bioenergy Task 37 - Country Reports Summary 2015. IEA Bioenergy. 2016. http://task37.ieabioenergy.com/country-reports.html?file=files/daten-redaktion/download/publications/ country-reports/Summary/IEA Bioerg+T37CRS+2015+Final.pdf.

[36] Wrońska I, Cybulska K. Quantity and quality of biogas produced from the poultry sludge optimized by filamentous fungi. Ecol Chem Eng S. 2018;25(3): 395-404. DOI: 10.1515/eces-2018-0027.

[37] Geršl M, Kanduč T, Matýsek D, Šotnar M, Mareček J. The role of mineral phases in the biogas production technology. Ecol Chem Eng S. 2018;25(1):51-59. DOI: 10.1515/eces-2018-0003.

[38] Biomethane in Transport. European Biogas Association. Brussels. 2016. http://european-biogas.eu/ wp-content/uploads/2016/05/BiomethInTransport.pdf. 
[39] Biofuel barometer. EurObserv'ER. July 2016. https://www.eurobserv-er.org/pdf/ biofuels-barometer-2016-en/.

[40] Current Super and Diesel Prices. All Petrol Stations in Germany. https://gasoline-germany.com/ preise-deutschland.phtml/statistics.

[41] Global Petrol Prices. Access mode: http://www.globalpetrolprices.com/lpg_prices/. April 2017.

[42] AZS.UA. http://azs.uapetrol.com/. April 2015.

[43] Petroleum \& Other Liquids. Independent Statistics \& Analysis. U.S. Energy Information Administration. 2017. https://www.eia.gov/petroleum/gasdiesel/.

[44] Energy and Environmental Affairs. 2017. http://www.mass.gov/eea/energy-utilities-clean-tech/ home-auto-fuel-price-info/gasoline-and-diesel-fuel-prices.html.

[45] Fuel prices in Sweden: petrol/gasoline and diesel. Sweden tips. 2017. http://www.swedentips.se/ travel-info/fuel-prices/.

[46] CNG Europe. 2017. http://cngeurope.com/.

[47] Petrol, diesel fuel, gas prices. 2017.http://www.benzin-price.ru/price.php?region_id=77.

[48] Current Fuel Prices in Europe. 2017. www.fuel-prices-europe.info.

[49] CNG Europe. 2017. http://cngeurope.com/countries/france/.

[50] Berg H, Burger A, Thiele K. Environmentally harmful subsidies in Germany. Federal Environment Agency. 2010. https://www.umweltbundesamt.de/sites/default/files/medien/publikation/long/3896.pdf. 